\title{
Climate change, vulnerability and securitization
}

DOI: http://dx.doi.org/10.1590/0034-7329202000114

Rev. Bras. Polít. Int., 63(1): e014, 2020

Revista Brasileira de Política Internacional ISSN 1983-3121

http://www.scielo.br/rbpi

\section{Cristiano Mendes ${ }^{1}$}

${ }^{1}$ Pontifícia Universidade Católica de Minas Gerais, Belo Horizonte, MG, Brazil (cristianomendes@pucminas.br).

iD ORCID ID:

orcid.org/0000-0002-5832-1777

\section{Letícia Britto dos Santos ${ }^{2}$}

2Pontifícia Universidade Católica de Minas Gerais, Belo Horizonte, MG, Brazil (letiicia@gmail.com).

iD ORCID ID:

orcid.org/0000-0003-1975-717X

\section{Matilde de Souza ${ }^{3}$}

${ }^{3}$ Pontifícia Universidade Católica de Minas Gerais, Belo Horizonte, MG, Brazil (matilde@pucminas.br).

\section{Copyright:}

- This is an open-access article distributed under the terms of a Creative Commons

Attribution License, which permits unrestricted use, distribution, and reproduction in any medium, provided that the original author and source are credited.

- Este é um artigo publicado em acesso aberto e distribuído sob os termos da Licença de Atribuição Creative Commons, que permite uso irrestrito, distribuição e reprodução em qualquer meio, desde que o autor e a fonte originais sejam creditados.
Received: June 10, 2020

Accepted: September 20, 2020

\section{Introduction}

\section{Abstract}

This article aims to examine whether vulnerability to Global Climate Change (GCC) increases or decreases a country's attempts to securitize the issue. The research was based on the hypothesis that the more vulnerable the country to GCC, the more likely it is for the government to securitize its agenda. Seven countries were analyzed according to the Notre Dame Global Adaptation Initiative (ND-GAIN), the climate vulnerability index. The conclusion is that the hypothesis does not stand, and new guidelines for further research were suggested.

Keywords: Climate change; Vulnerability; Securitization and global environmental politics.

\author{
Accepted: September 20,2020
}

$\mathrm{O}$ n May 15, 2018, during an event at the Austrian World Summit (R20), António Guterres, Secretary-General of the United Nations (UN), spoke about global warming and the security challenges posed by climate change on our planet. According to Guterres, climate change imposes a sense of urgency in the search for solutions to adapt to the changes brought about by global warming. Still according to Guterres, this represents an existential threat to humanity, and the search for clean and renewable energy sources must not wait for the end of coal and oil reserves. This speech meets the new security narratives that started to expand after the end of the Cold War.

Considering this tendency, scholars and political leaders have been warning about the consequences of climate change. According to academics and decision-makers, these climate changes can be an existential threat to humanity and ecosystems, since 
their consequences endanger all life on Earth. Concurrent with these discussions, there are also studies on the vulnerability of States to such changes.

Along with this discussion, there are studies on the vulnerability of countries facing these changes. How and to what extent each nation will be affected by changes taking place outside its territory, as well as the ability to cope with them, are issues that came into the international agenda in this period (Guzzini 2004; Herring 2007; Malik 2015).

The research on which this paper is based began with the question: Does a country's vulnerability to GCC increase or decrease the government's likelihood to securitize the issue? The hypothesis that was tested was that the more vulnerable a country to GCC, the more likely it is that the government securitizes the issue. In order to test this, seven countries were chosen as case studies: South Africa, Germany, Australia, Brazil, Mauritius, Rwanda and São Tomé and Príncipe. The criteria guiding this choice will be clarified subsequently.

Considering that this theme involves many aspects, it is important to note that the present study does not intend to verify if the attempts of climate change securitization by the governments will be effective to influence audiences or to support the inclusion of climate change in the United Nations Security Council (UNSC) agenda. These analyses would demand the verification of different audiences' acceptance of the securitization movements in the documents of the UNSC, which are outside the scope of this study.

This article is divided into four sections, besides this introduction and a conclusion. In the first section, conceptual categories related to vulnerability and security will be introduced, according to International Relations theories. The second section explains the vulnerability to GCC of each of the chosen countries. The third section compares previous case studies and debates possible pushes for securitization in the studied countries. The fourth and final section takes this comparison further, aiming to refine the investigation of the hypothesis.

\section{Vulnerability to climate change}

Vulnerability to climate change guides the discussion, given the impacts caused by this phenomenon, the risks and threats to human life, and the general conditions for sustaining life on the planet produced by it (Pratt et al. 2004; Chen et al. 2015; Nunes 2016).

Vulnerability is a very broad and controversial concept. ${ }^{1}$ It has been used to deal with many different issues, which involve, among others: the general idea of vulnerability, which encompasses its broader dimension, related to risks and threats of various types, origins and causes (Keohane 1995); the idea of environmental vulnerability, which focuses on environmental risks and threats, including, for instance, natural events and disasters. The Intergovernmental Panel on Climate Change' (IPCC) reports define vulnerability as a degree to which a system is susceptible to and is

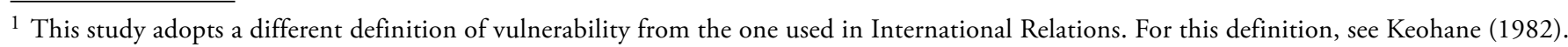


unable to cope with adverse effects of climate change (McCarthy et al. 2001). The IPCC reports have detailed accounts of varying degrees of exposure and vulnerability. According to Adger (2006), the key parameters of vulnerability, based on the exposure and its adaptive capacity, are the stress to which a social-ecological system is exposed, the response of the system and the capacity for adaptive action.

Vulnerability to Global Climate Change considers the impact of these phenomena as risks and threats to human life and to the planet's general capacity to sustain life (Pratt et al. 2004; Chen et al. 2015), and it will be the guideline for this article.

There were many efforts to reach more conceptual precision and to establish adequate parameters to measure vulnerability. As there is a space limit here, this debate will not be brought forth. Instead, the Notre Dame-Global Adaptation Index (ND-GAIN) was used, as it is an adequate concept and index of vulnerability for the purpose of this paper, especially because this index deals specifically with aspects of the GCC.

The index organizes data on vulnerability in two different dimensions: vulnerability and readiness. It measures a country's vulnerability according to six life-supporting sectors: food, water, health, ecosystem services, human habitat and infrastructure. The index takes cross-sectional components into account for each sector. Readiness, on the other hand, is measured based on the country's ability to respond to social, economic and governance issues. Based on these elements, Chen et al. (2015) designed the index according to figure 1.

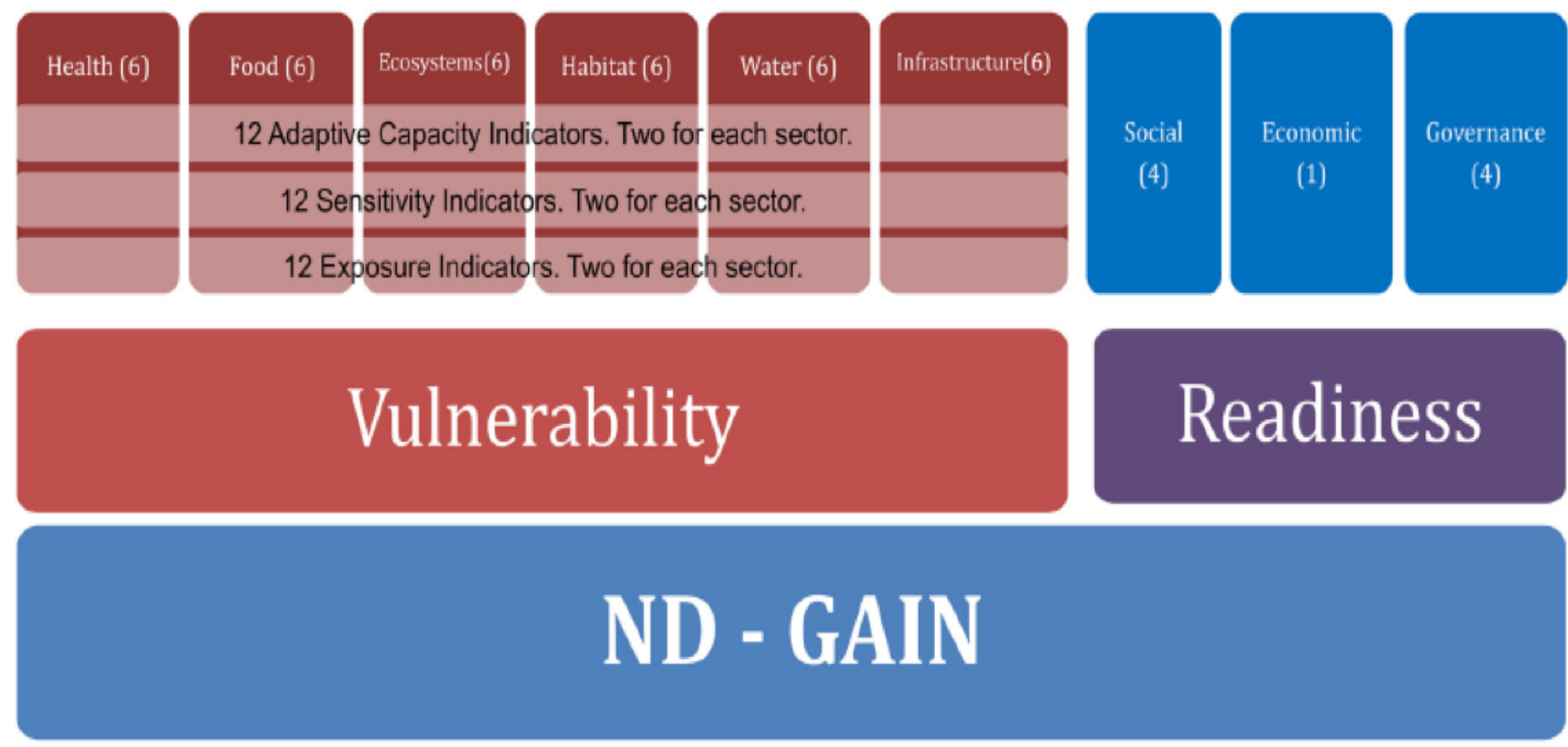

Source: Chen et al. 2015 p. 6.

Figure 1 - Summary of ND-GAIN's Vulnerability and Readiness indicators

The cross-sectional components of vulnerability are: exposition, sensitivity and capacity to adapt, as described in Table 1. 
Table 1. Definition of Vulnerability and Readiness components

\begin{tabular}{ll}
\hline \multicolumn{1}{c}{ Vulnerability } & \multicolumn{1}{c}{ Definition } \\
Exposition & $\begin{array}{l}\text { Measures the extent to which a human society and its support sectors are affected } \\
\text { by climate change. On the ND-GAIN, this component's goal is to capture physical } \\
\text { factors alien to the system that increase vulnerability. } \\
\text { Extent to which people and sectors on which they depend are affected by climate } \\
\text { disturbances. Factors that increase sensitivity are the dependence on sectors sensitive } \\
\text { to climate and the share of the population sensitive to climate risks. } \\
\text { Sensitivity }\end{array}$ \\
$\begin{array}{l}\text { Measures society and its supporting sectors' ability to adjust in order to reduce } \\
\text { potential damages, as well as to respond to the negative consequences of climate } \\
\text { events. These indicators capture the readily available means in specific sectors to deal } \\
\text { with the impacts of climate change. }\end{array}$ \\
\hline Readiness & \multicolumn{1}{c}{ Definition } \\
\hline Economic & $\begin{array}{l}\text { Examines the tendency of investments that promote private sector capital mobilization. } \\
\text { Measures society stability and institutional arrangements that contribute to } \\
\text { investment risks. } \\
\text { Social }\end{array}$ \\
\hline
\end{tabular}

Source: Chen et al. 2015

ND-GAIN adopted 74 different variables, comprising 45 indicators, which involve vulnerability and readiness. Each country's score is determined according to these variables and indicators, also considering the six life-supporting sectors. Based on this information, countries are ranked according to a matrix that coordinates both these dimensions:

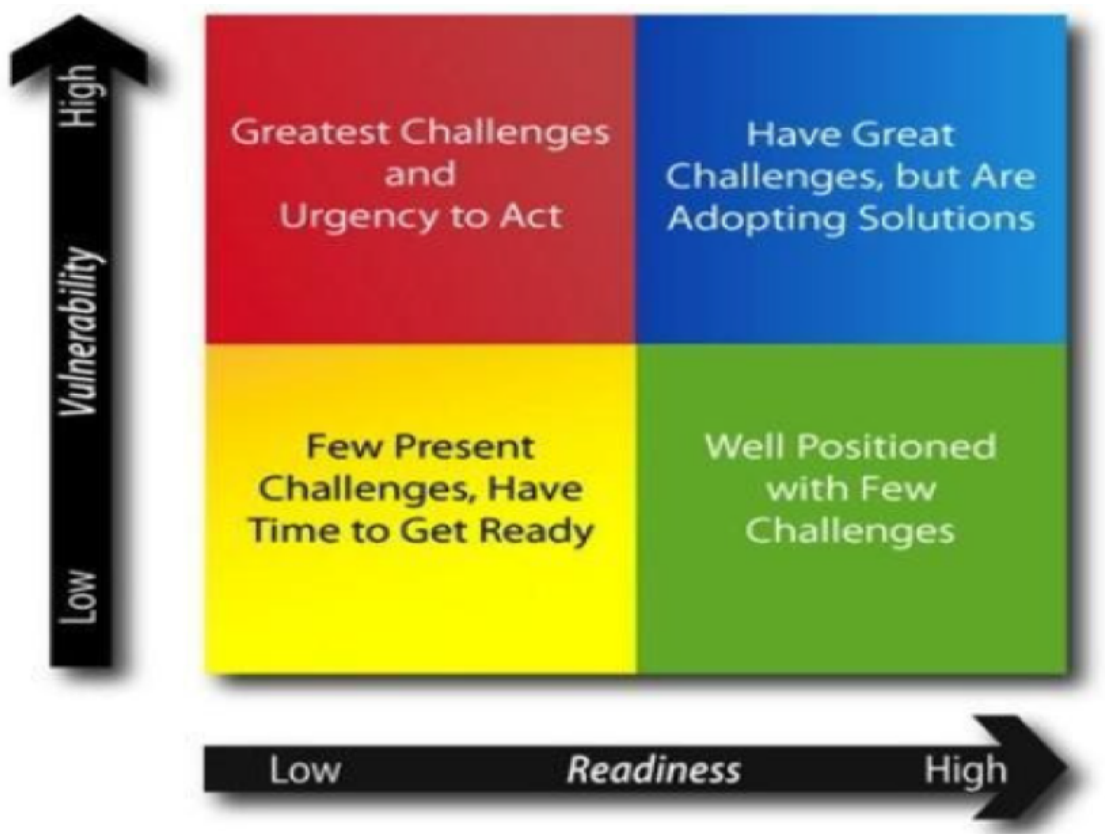

Source: Chen et al. 2015, p. 9.

Figure 2. ND-GAIN Matrix 
In environmental studies, vulnerability is considered a "propensity or predisposition of human societies to be negatively impacted by climate hazards." Readiness is the countries' ability "to make effective use of investments for adaptation actions thanks to a safe and efficient business environment" (Chen et al. 2015, 3-4).

Considering the definition of the index, it must be pointed out that:

Adaptation is an evolving concept. Our understanding of climate change and the risks it presents is constantly improving through ongoing research. At ND-GAIN, we strive to estimate adaptation risk and opportunity using the best available research outputs, data, and tools (Chen et al. 2015, 2).

The authors admit that all countries face challenges adapting to GCC, albeit in different degrees, not only due to its geographic location but also due to social-economic circumstances. Besides, some countries are more prepared than others to carry out adaptation practices which lead to government actions or a prompter response from the private sector. In this case, they have more public or private investment capacity, a well-developed institutional framework that allows for government action, or better knowledge of the problem.

\section{Securitization and environmental security}

The Copenhagen School (CS) is one of the main schools of thought on international security created after the Cold War. By confronting traditional approaches to studies on strategy and security, CS tried to expand the number of subjects that could be studied in this perspective, while introducing new interpretations into the academic debate.

For the Copenhagen School, any phenomenon perceived as an existential threat can become a security issue, triggering emergency measures and leading the way for exceptional policies to become a viable option. Accordingly, security-related matters might be interpreted as a process of political polarization, in a spectrum that includes non-politicized security matters, as well as the standard politicization of a certain topic. Consequently, it is not an intrinsic characteristic that turns a phenomenon into a security issue, but a speech act (Floyd and Mathew 2013) through tacit negotiations between securitizing agents and audiences. This makes it a priority in the political agenda, as it represents an existential threat to a reference object (Buzan et al. 1998).

Accordingly, any phenomenon's securitization process involves three elements: identifying the existential target under threat; identifying the situation as an emergency; and identifying the possibility to deal with the situation with exceptional measures (Buzan et al. 1998). Thus, the process of securitization is marked by increased politicization, turning the subject away from a non-political situation into a range that goes beyond normal politics. Securitizing, therefore, means prioritizing a certain subject for considering it an existential threat to a reference object (Figure 3 ). 


\section{Figure 3. Politicization and Securitization}

The Copenhagen School's success after the Cold War led many international agendas to start dealing with issues that were not previously seen through the security lens. Subjects like economics, human rights and the environment turned into security issues, and were dealt with as a priority. Besides, new reference objects were gradually perceived as eligible for protection by the International Community.

Environmental security refers to the study of the ecological pillars of our civilization, and it seeks means to ensure ecologically sustainable development. In principle, this sector holds ecosystems and species as reference objects, and pollution, global warming and habitat destruction as threats (Moller 2005, 22). Climate change and temperature rise on Earth can lead to desertification, floods, forced migration, among many other consequences. Habitat change, rising ocean levels and increased number and intensity of storms can put human lives in danger and lead to unsuitable living conditions. Treating the environment as a sector of international security is vital for a holistic analysis of the threats to humankind.

\section{Case study: climate vulnerability}

In order to test the proposed hypothesis, seven countries were picked out: Germany, South Africa, Australia, Brazil, Mauritius, São Tomé and Príncipe and Rwanda. Among the less vulnerable countries, the choice of Germany is justified by the fact that it is one of the most relevant countries in the Global Climate Change Regime (GCCR), and it plays an important role in the environmental agenda since the 1970s. It is among the 10 least vulnerable countries, ranking $9^{\text {th }}$ in climate vulnerability and also $9^{\text {th }}$ in greenhouse gas emissions, with 1,98\% of global emissions in 2017 (ND-GAIN). Australia ranks $5^{\text {th }}$. It is a large island with extremely low vulnerability, although rising sea levels might affect the coast. It is responsible for $1,28 \%$ of global greenhouse gas emissions.

Among the medium-ranking countries, South Africa was chosen because it is an important emerging nation, member of the BASIC group (Brazil, South Africa, India and China, which acts before the GCCR), and is responsible for $1,13 \%$ of global emissions. Brazil is an important 
country in negotiations on GCC, despite criticism on its conservative negotiation stances (Viola and Franchini 2013). Brazil ranks $80^{\text {th }}$, considered of medium vulnerability, and contributes to $2,25 \%$ of global emissions. Also of medium vulnerability, the island country of Mauritius is situated in the Indic Ocean, $2000 \mathrm{~km}$ from the African coast. It ranks $50^{\text {th }}$ in ND-GAIN, in a considerably more comfortable situation than South Africa or Brazil. Its ranking is more closely related to readiness than vulnerability. Mauritius and São Tomé and Príncipe are members of the Alliance of Small Island States (AOSIS), a league of small island countries in the GCCR whose goal is to increase its capacity for dialogue in GCC-related negotiations.

São Tomé and Príncipe and Rwanda were the countries chosen among those with high vulnerability. São Tomé and Príncipe, just like Mauritius, is responsible for virtually no emissions. Located at the Gulf of Guinea, on the West coast of the African continent, Sáo Tomé and Príncipe ranks $116^{\text {th }}$, with low readiness in regard to challenges imposed by climate change. Lastly, Rwanda is a landlocked country located in the African Great Lakes Region. It ranks $114^{\text {th }}$ at the ND-GAIN and is considered extremely vulnerable, but its readiness is better than that of São Tomé and Príncipe.

Due to their very different positions, these cases can shed light on the existence or absence of correlation between climate vulnerability and the tendency to securitize the issue. Table 2 shows each of the seven countries' ranking at the ND-GAIN, considering the total score, as well as those for vulnerability and readiness.

Table 2. Countries' ranking at the ND-GAIN, considering total score, vulnerability and readiness, 2017.

\begin{tabular}{|c|c|c|c|}
\hline \multirow{2}{*}{ Country } & \multicolumn{3}{|c|}{ Score } \\
\hline & General - ND- GAIN & Vulnerability & Readiness \\
\hline Germany & 9 th & 4 th & 16th \\
\hline Australia & 5 th & 5 th & 10th \\
\hline South Africa & 81 st & 74th & 97 th \\
\hline Brazil & 80 th & $53 \mathrm{rd}$ & 105 th \\
\hline Mauritius & 50 th & 100 th & 37 th \\
\hline São Tomé and Príncipe & 116th & 120 th & 128th \\
\hline Rwanda & 114 th & $153 \mathrm{rd}$ & 94 th \\
\hline
\end{tabular}

Source: Own elaboration based on Notre Dame global adaptation initiative: download data (2020). ${ }^{2}$

Since the goal of this article is to debate the States' tendency to securitize climate change, and considering the proposed hypothesis, the countries' climate vulnerability index will be discussed and compared below. Subsequently, their positions on securitization will be analyzed.

2 The Database is available to any researcher on: Notre Dame global adaptation initiative: download data (2020). 


\section{Time-series plot of ND_GAIN}

Notre Dame Global Adaptation Index. Data release Nov. 2015

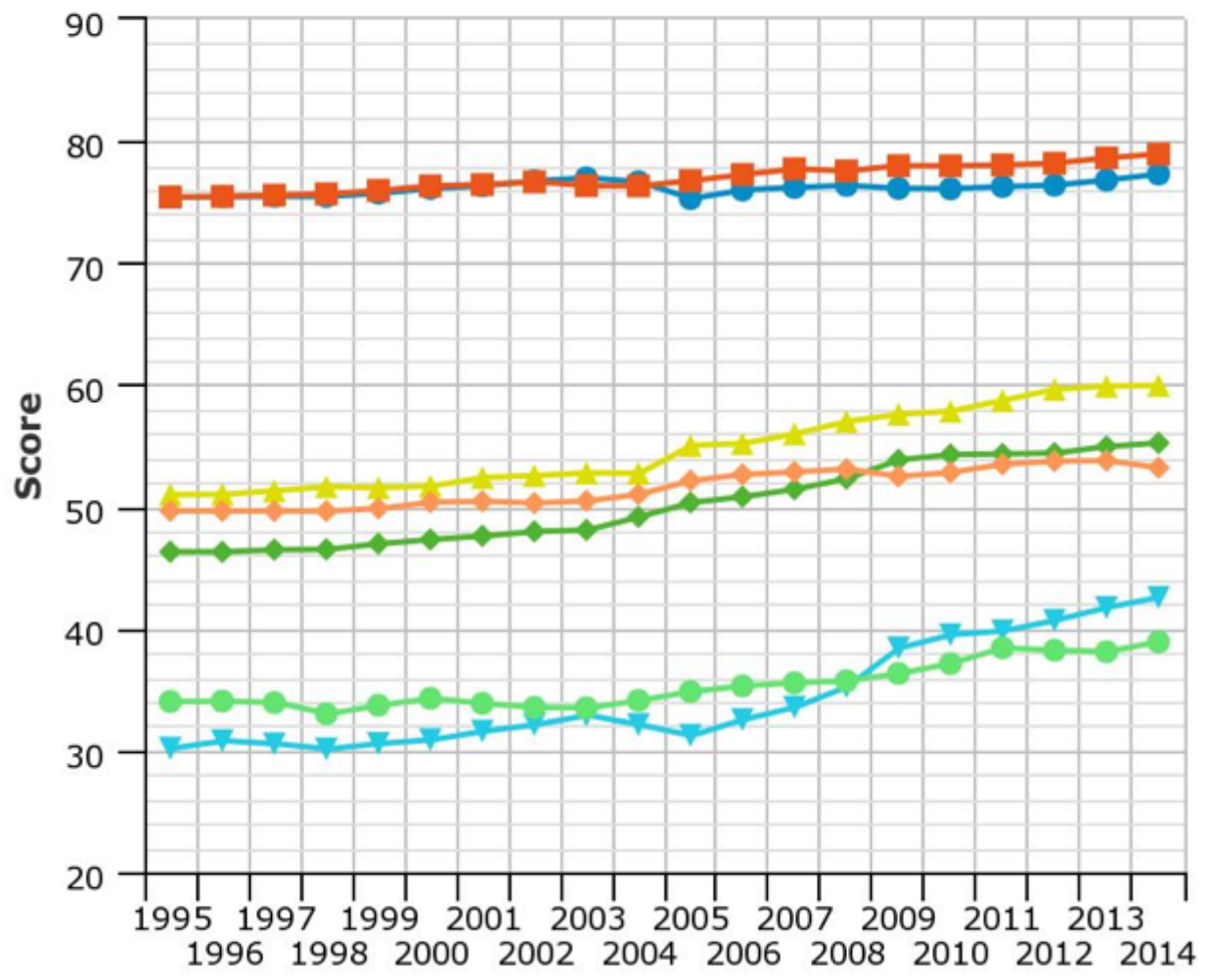

Australia

$\leadsto$ Brazil

- - Germany

- Mauritius

- Rwanda

- Sao Tome and Principe

$\rightarrow$ South Africa

Source: Own elaboration based on Notre Dame global adaptation initiative: download data (2020).

\section{Chart 1. Vulnerability index of analyzed countries - 2014.}

Chart 1 shows the countries' ranking in the ND-GAIN vulnerability index, as well as variation on vulnerability through time. All of the countries improved their situation since 1995, which signals that they were able to reduce their vulnerability to GCC. In relative terms, Rwanda was the country that improved the most.

The following charts explore ND-GAIN information, taking into account the components of sensitivity, exposure and capacity to adapt in the dimension of vulnerability. In the case of readiness, the economic, governance and social components will also be presented. All of the components' variables will be contemplated. In some cases, these variables will be divided into indicators in order to identify each country's biggest challenges when facing GCC. The data was organized into graphs, followed by a summary of the information in Table 3 to permit easy reading. The analyzed data was collected in 2014, which is the most recent period with available information. In order to debate and observe each of the analyzed components, the focus will be on the variables and indicators in which countries score 0,5 or higher, according to their vulnerability. ${ }^{3}$

\footnotetext{
${ }^{3}$ For vulnerability, the interpretation is that the closer to 1 , the more vulnerable the country in regard to the analyzed variable/indicator, and the closer to 0 , the less vulnerable.
} 
In the following charts, which deal with vulnerability, there is general data on vulnerability, as well as data for each of the components of vulnerability, in which there are some indicators of the aforementioned variables, so as to enable a more focused debate on the aspect of securitization.

\section{Component plot of Vulnerability(2014)}

Notre Dame Global Adaptation Index. Data release Nov. 2015

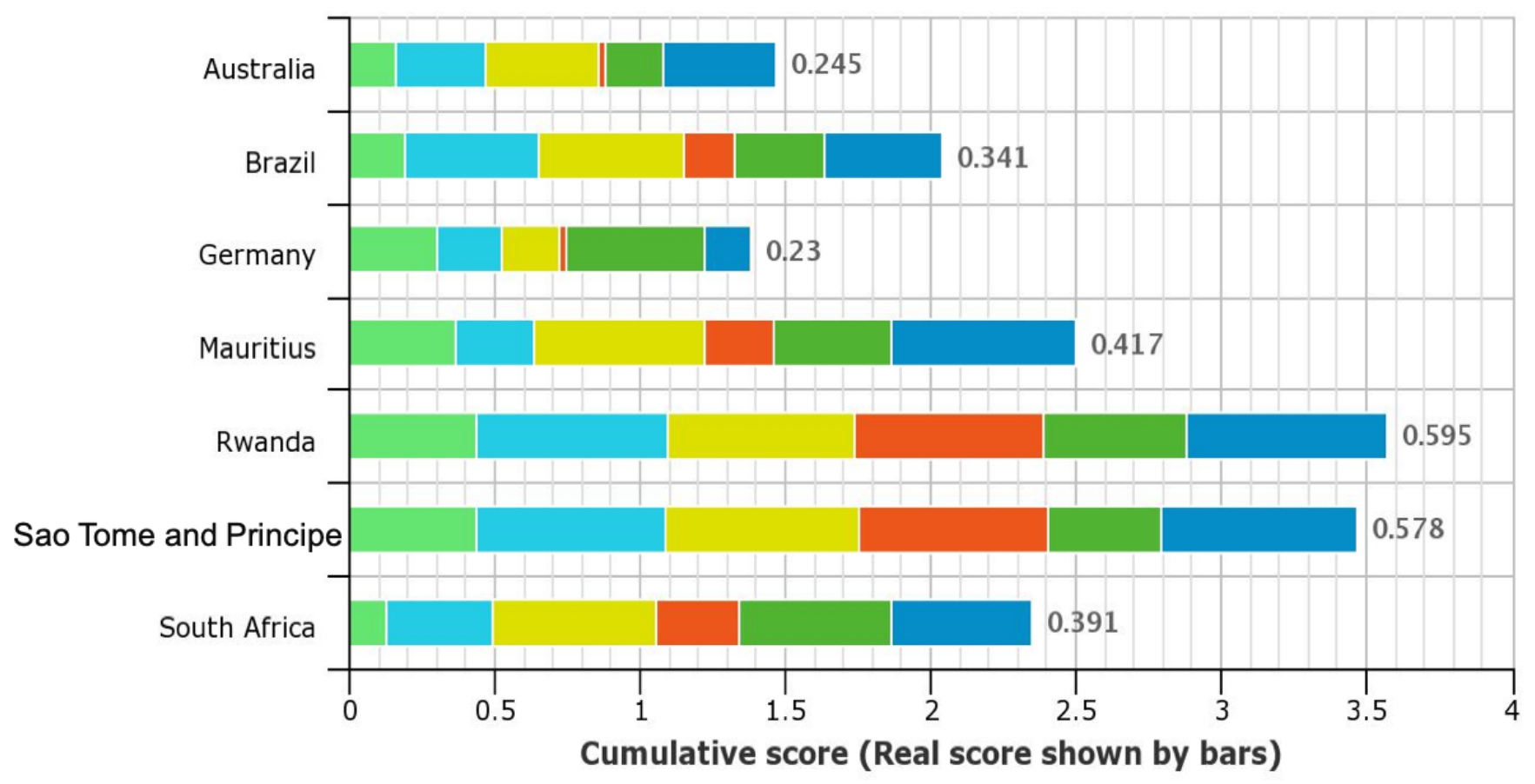

Food Water Health Ecosystems Habitat Infrastructure

Source: Own elaboration based on Notre Dame global adaptation initiative: download data (2020).

Chart 2. Variables of Vulnerability - 2014

Table 3. Systematization of data on variables of vulnerability

\begin{tabular}{ll}
\hline \multicolumn{1}{c}{ Variables of vulnerability } & Most vulnerable countries $(\mathbf{0 , 5}$ or higher $)$ \\
\hline Food & Rwanda, São Tomé and Príncipe and Mauritius \\
Water & All countries are below 0,5 \\
Health & São Tomé and Príncipe and Rwanda \\
Ecosystem & São Tomé and Príncipe, Rwanda, Mauritius and South \\
Human habitat & Africa \\
Infrastructure & Rwanda, São Tomé and Príncipe and South Africa \\
\hline
\end{tabular}

Source: Own elaboration based on Notre Dame global adaptation initiative: download data (2020). 
Still on the dimension of vulnerability, Chart 3 explores the component of sensitivity, taking into account indicators of the variables selected (food, water, health, ecosystem services, human habitat and infrastructure). The aspects analyzed are: dependence on food imports, rural population, rate of drinking water abstraction, dependence on foreign resources for health services, population in inadequate housing (slums), dependence on natural capital, ecological footprint, urban concentration, share of the population in each age group, dependence on energy imports, population living in areas less than 5 meters above sea level. ${ }^{4}$

\section{Component plot of Sensitivity(2014)}

\section{Notre Dame Global Adaptation Index. Data release Nov. 2015}

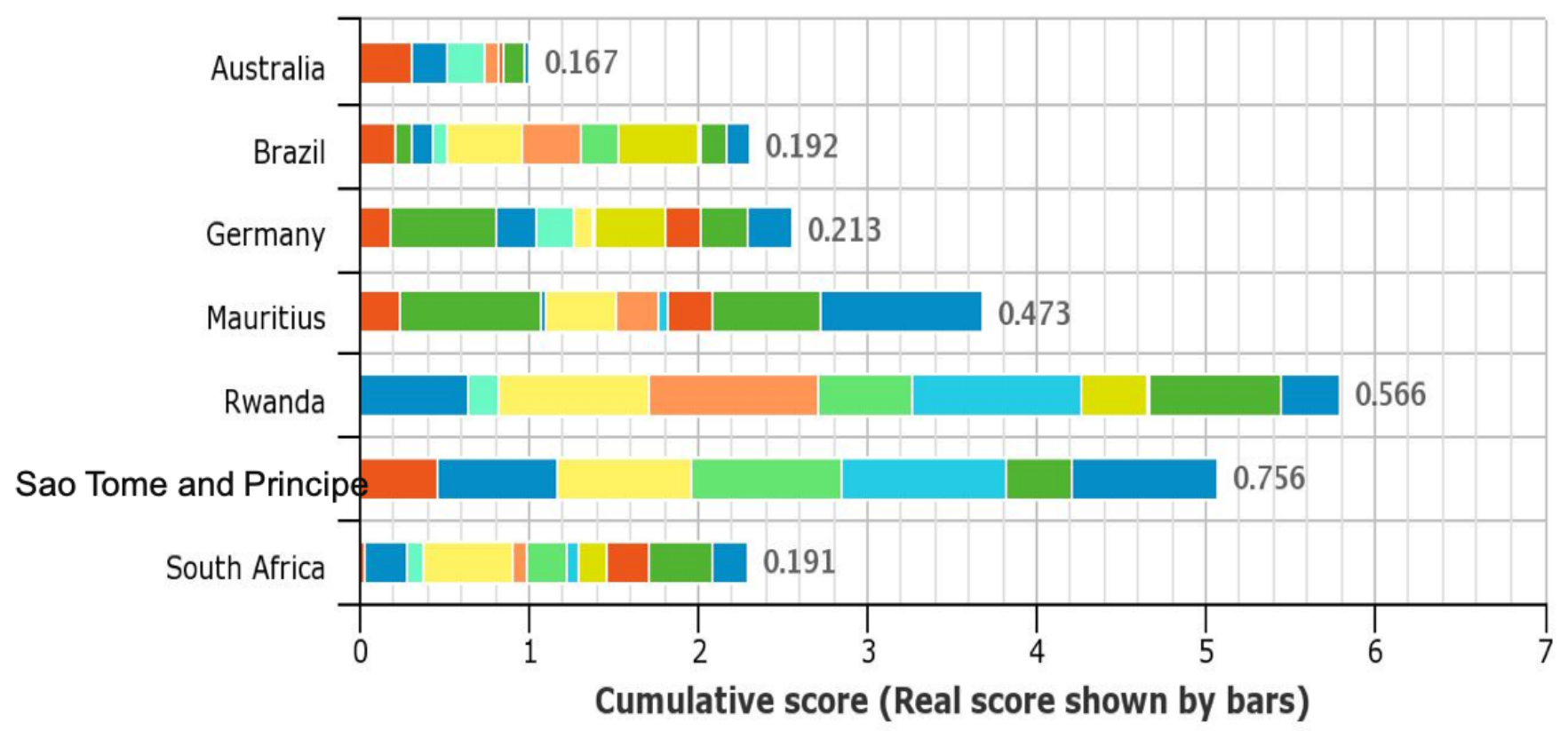

food import dependency rural population_ fresh water withdrawal rate water dependency ratio $\square$ dependency on external resource for health service slum population natural capital dependency ecological footprint urban concentration age dependency ratio dependency on imported energy population living under $5 \mathrm{~m}$ above sea level

Source: Own elaboration based on Notre Dame global adaptation initiative: download data (2020).

\section{Chart 3. Sensitivity - 2014}

Table 4 organizes the information on chart 3, in order to permit easy visualization of the indicators to which the countries are more sensitive.

\footnotetext{
${ }^{4}$ Explaining some indicators: 1) Projected population change - involves change in consumption patterns, vital for food and power demand, as well as changes in the population growth rate. 2) Projected change of biome distribution - captures change in a biome's function, considering climate change and its impacts on areas covered by different biomes in a given country. 3) Age dependency ratio - involves changes in the age pyramid, as it considers the age groups 14 years old and lower, as well as 65 years old and higher, the most vulnerable ones.
} 
Table 4. Systematization of data on countries' sensitivity to each indicator.

\begin{tabular}{ll}
\hline \multicolumn{1}{c}{ Sensitivity indicators } & Most sensitive countries (0,5 and higher) \\
\hline Food import & Mauritius and São Tomé and Príncipe \\
Rural population & Mauritius and Rwanda \\
Dependence on foreign resources for health services & Rwanda and São Tomé and Príncipe \\
Population living in slums & Rwanda and São Tomé and Príncipe \\
Dependence on natural capital & Rwanda \\
Ecological footprint & Rwanda, São Tomé and Príncipe and South Africa \\
Changes in the age pyramid & Rwanda and São Tomé and Príncipe \\
Energy import & Germany and Mauritius (no data for Rwanda and São \\
\hline
\end{tabular}

Source: Own elaboration based on Notre Dame global adaptation initiative: download data (2020).

In regard to the second great group of elements that composes the analytical category of vulnerability, chart 4 clarifies the countries' and the populations' exposure to GCC.

\section{Component plot of Exposure(2014)}

Notre Dame Global Adaptation Index. Data release Nov. 2015

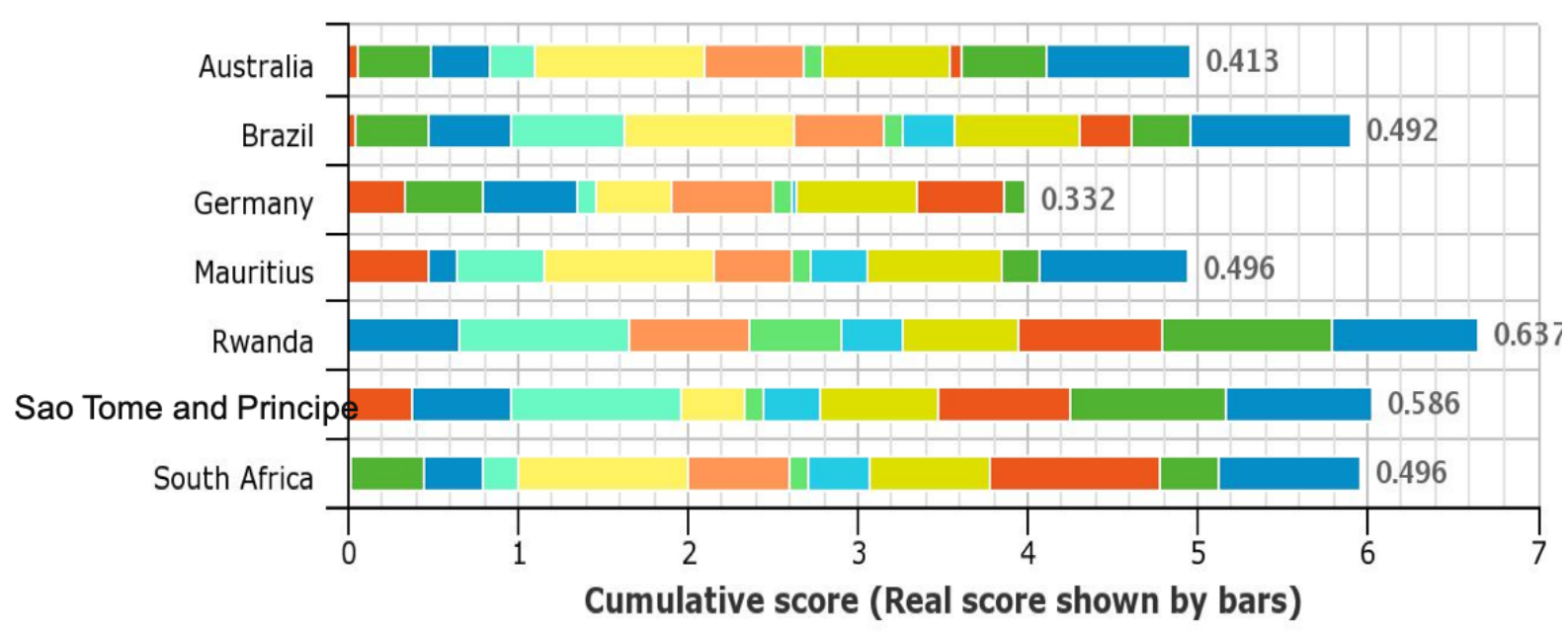

projected change of cereal yields $\square$ projected population change

projected change of annual runoff projected change of annual groundwater recharge

projected change of deaths from climate change induced diseases

projected change in vector-borne diseases projected change of biome distribution

projected change of marine biodiversity projected change of warm periods

projected change of flood hazard — projected change of hydropower generation capacity

projected change of sea level rise impacts 
Table 5 shows the level of exposure of the countries, taking into account the different variable indicators observed.

Table 5. Systematization of data on the countries' exposure in regard to each indicator.

\begin{tabular}{ll}
\hline \multicolumn{1}{c}{ Exposure indicators } & \multicolumn{1}{c}{ Most vulnerable countries (0,5 or higher) } \\
\hline Expected change of grains yields & Australia, Rwanda and São Tomé and Príncipe \\
Expected population change & $\begin{array}{l}\text { Australia, Rwanda and São Tomé and Príncipe } \\
\text { Australia, Germany, Rwanda, São Tomé and Príncipe } \\
\text { and South Africa (no data for Mauritius) }\end{array}$ \\
Expected change of river basin outflow & $\begin{array}{l}\text { Australia, Germany, Brazil, Mauritius, Rwanda, São } \\
\text { Tomé and Príncipe and South Africa }\end{array}$ \\
Expected change of groundwater recharge & $\begin{array}{l}\text { All countries are below 0,3 in exposure } \\
\text { Expected change of deaths caused by climate change- } \\
\text { related diseases }\end{array}$ \\
Expected change of vector-borne diseases & $\begin{array}{l}\text { Rwanda } \\
\text { Australia, Germany, Brazil, Rwanda and South Africa } \\
\text { (no data for São Tomé and Príncipe) }\end{array}$ \\
Expected change of biome distribution & Australia, Brazil, Mauritius and South Africa \\
Expected change of marine biodiversity & Brazil, Mauritius, Rwanda and São Tomé and Príncipe \\
Expected change of periods with higher temperature & Germany, Brazil, Rwanda and São Tomé and Príncipe \\
Expected change of flooding risks & $\begin{array}{l}\text { Rwanda and São Tomé and Príncipe (no data for } \\
\text { Mauritius) }\end{array}$ \\
Expected change of hydropower generation capacity & Mauritius \\
Expected change of impacts related to rising sea levels
\end{tabular}

Source: Own elaboration based on Notre Dame global adaptation initiative: download data (2020).

It must be pointed out that all analyzed countries are vulnerable when it comes to water resources, be it on river basin outflow, or groundwater recharge. This exposure might lead to the securitization of the matter, considering the possibility that countries might act to ensure water supply.

Chart 5 presents each country, society and its sectors' ability to adjust in order to reduce potential damage and to respond to negative consequences of climate events, the so-called capacity to adapt. 


\section{Component plot of Capacity(2014)}

Notre Dame Global Adaptation Index. Data release Nov. 2015

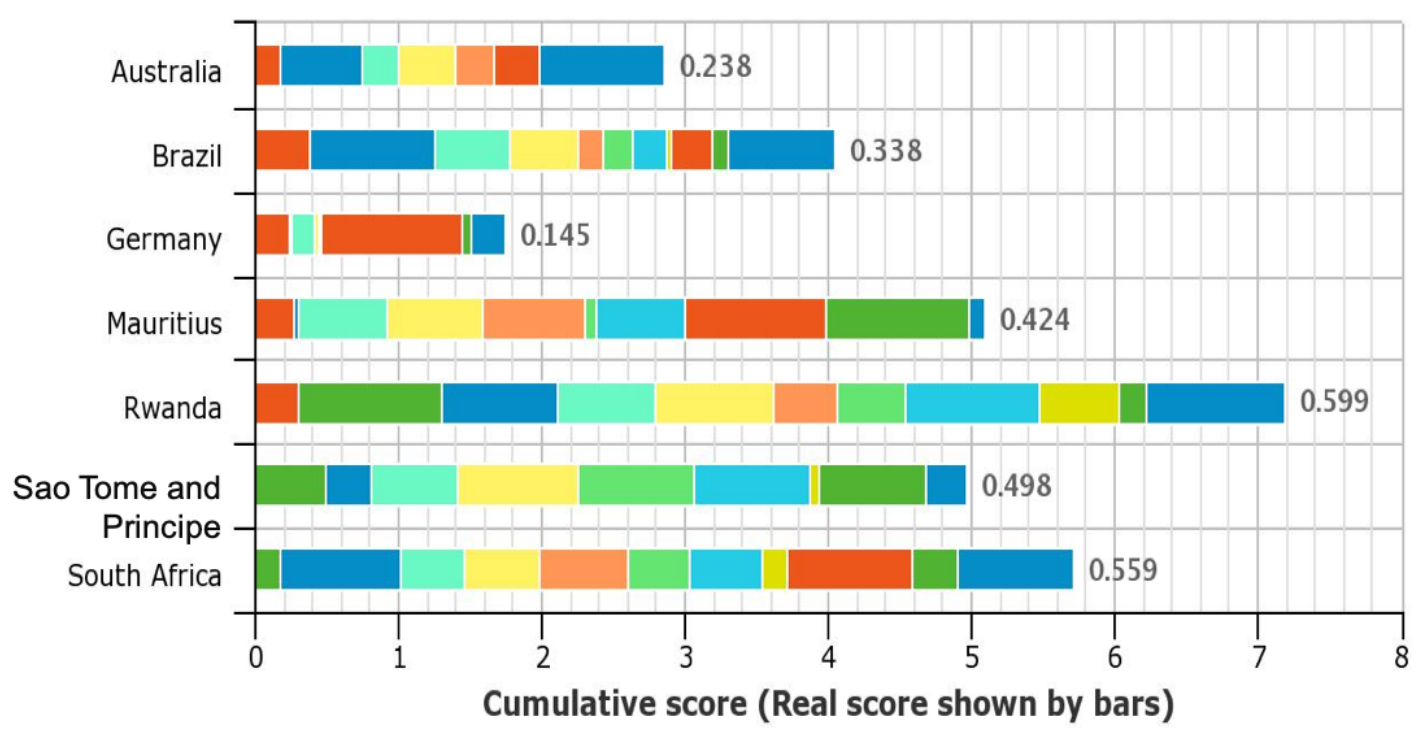

agriculture capacity child malnutrition dam capacity access to reliable drinking water medical staff access to improved sanitation facilities protected biome engagement in international environmental conventior quality of trade and transport infrastructure paved roads electricity access disaster preparedness

Source: Own elaboration based on Notre Dame global adaptation initiative: download data (2020).

Chart 5. Capacity to adapt, 2014

Table 6. Systematization of data on the countries' capacity to adapt in regard to each indicator

\section{Capacity indicators}

Agricultural capacity

Child malnourishment

Capacity to store water in dams

Access to drinkable water

Medical Staff

Access to basic sanitation

Protected biomes

Engagement in international environmental conventions

Quality of transport and commercial infrastructure

Road pavimentation

Access to electricity

Disaster prevention

\section{Least capable countries}

Australia, Brazil, Rwanda and South Africa

Mauritius and São Tomé and Príncipe

Germany, Mauritius and South Africa (no data for

Rwanda and São Tomé and Príncipe)

Rwanda

Rwanda, São Tomé and Príncipe and South Africa

São Tomé and Príncipe

Mauritius and South Africa (no data for São Tomé and Príncipe)

Mauritius, Rwanda, São Tomé and Príncipe and South Africa

Brazil, Mauritius, Rwanda and São Tomé and Príncipe

Australia, Brazil, Rwanda and South Africa

Rwanda

All countries scored less than 0,37 (No data for São Tomé and Príncipe and South Africa)

Source: Own elaboration based on Notre Dame global adaptation initiative: download data (2020). 

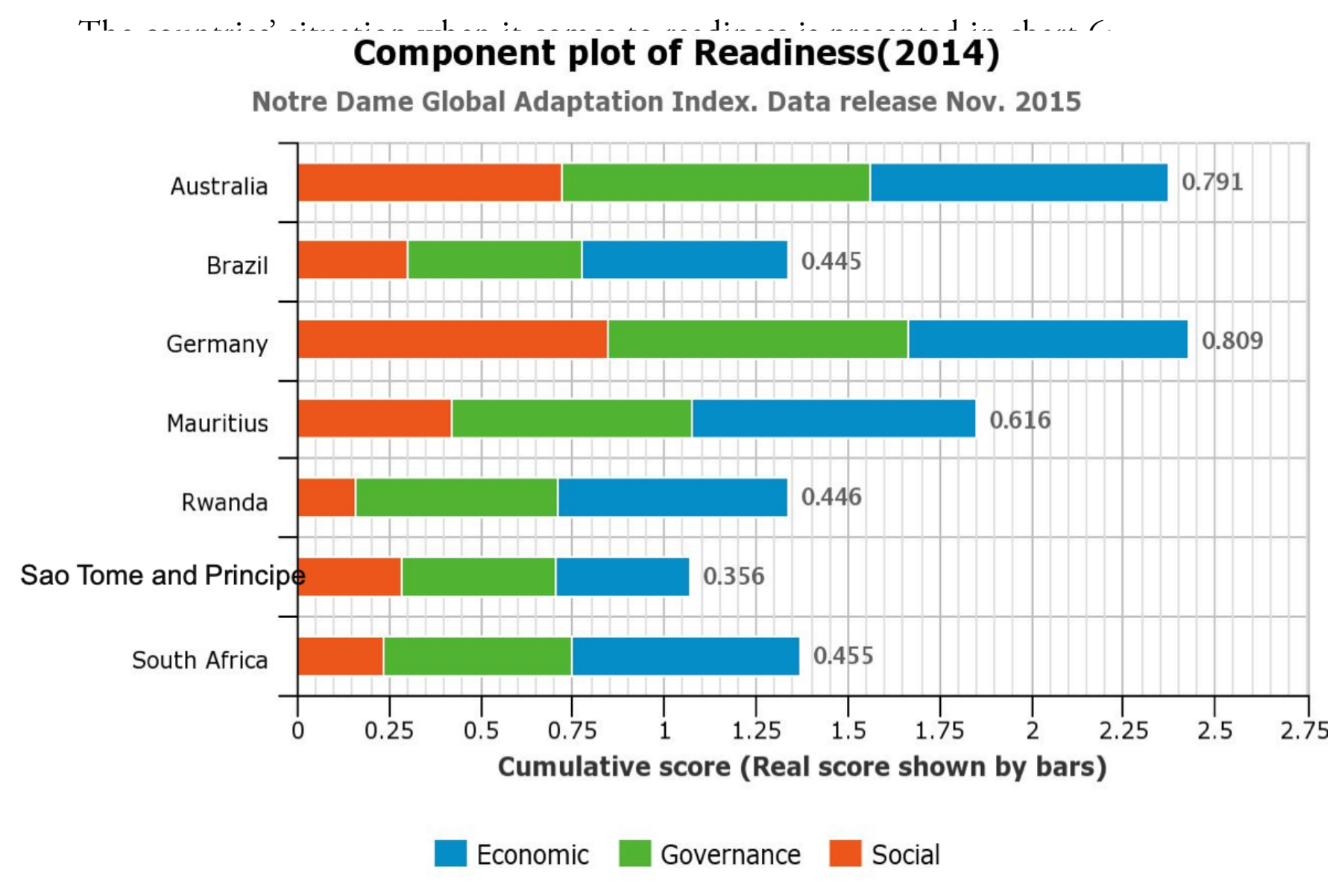

Source: Own elaboration based on Notre Dame global adaptation initiative: download data (2020).

Chart 6. Readiness, 2014

In order to read the data on readiness, one must know that the closer a country is to 1 , the more capable it is. Germany has the highest ability to respond in all readiness components, followed by Australia. When it comes to the economic component, Sáo Tomé and Príncipe is the least capable. As for the component of governance, São Tomé and Príncipe and Brazil are the least capable ones. For the social component, Rwanda, South Africa, São Tomé and Príncipe, Brazil and Mauritius are the least capable ones.

When expanding on the components to observe the variables, it was noted that the variable 'economy' only has one indicator (doing business), which evaluates the investment tendency that promotes mobilization of private capital. This indicator is valid for the dimension of readiness in the global index of climate vulnerability. The information on the countries for this specific variable is demonstrated on chart 7. 


\section{Component plot of Governance(2014)}

Notre Dame Global Adaptation Index. Data release Nov. 2015

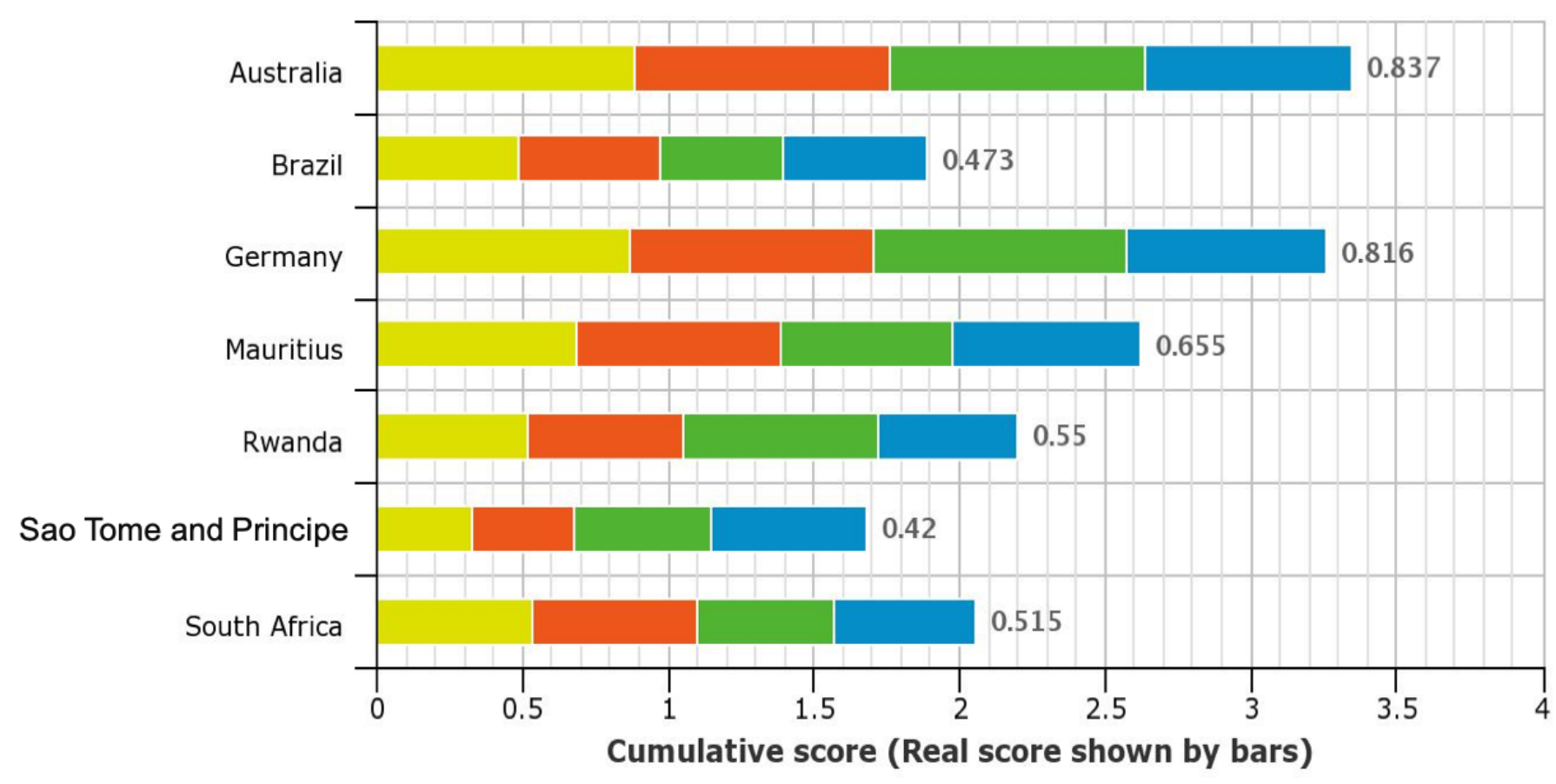

political stability and non-violence $\square$ control of corruption $\square$ regulatory quality rule of law

Source: Own elaboration based on Notre Dame global adaptation initiative: download data (2020).

\section{Chart 7. Governance, 2014}

Table 7 shows the countries with the lowest capacity for each governance variable.

Table 7. Systematization of data on governance indicators, 2014.

\begin{tabular}{ll}
\hline \multicolumn{1}{c}{ Governance variables } & \multicolumn{1}{c}{ Countries with the lowest capacity $(\mathbf{0 , 5}$ or lower $)$} \\
\hline Political stability and non-violence & Rwanda, South Africa and Brazil \\
Control of corruption & Brazil, São Tomé and Príncipe and South Africa \\
Regulatory quality & São Tomé and Príncipe and Brazil \\
Rule of law & São Tomé and Príncipe and Brazil \\
\hline
\end{tabular}

Source: Own elaboration based on Notre Dame global adaptation initiative: download data (2020).

Brazil is the only country among the least capable in all variables measured for the governance component, although São Tomé and Príncipe is only slightly above it in the political stability and non-violence variable, with a score of 0,53 .

Chart 8 shows the social conditional indicators as social inequality, ICT infrastructure and Education for each country. 


\section{Component plot of Social(2014)}

Notre Dame Global Adaptation Index. Data release Nov. 2015

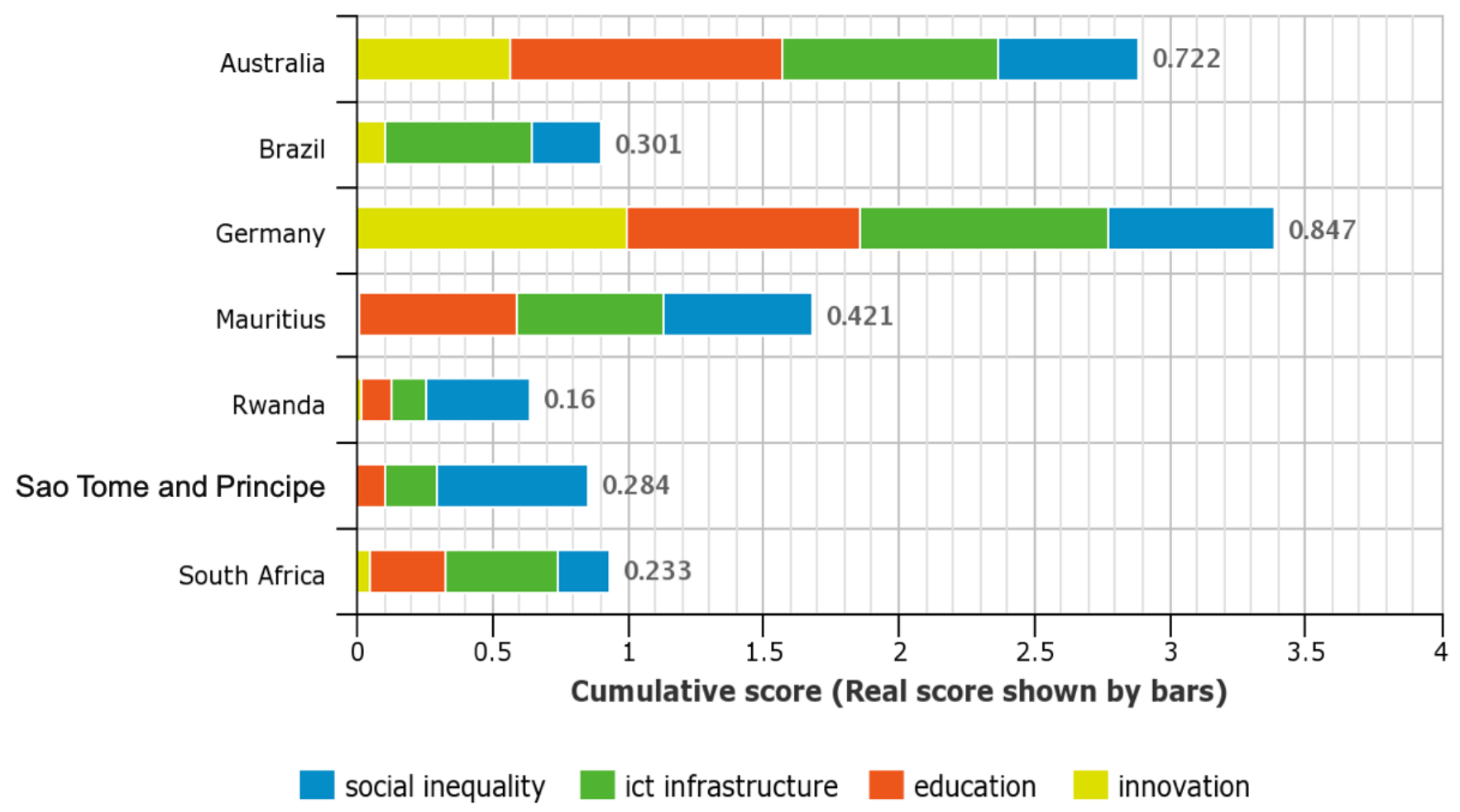

Source: Own elaboration based on Notre Dame global adaptation initiative: download data (2020)

Chart 8. Social Conditions, 2014.

Table 8 presents the three countries with the worst conditions for each social indicator.

Table 8. Systematization of data on social conditions indicators, 2014

\begin{tabular}{ll}
\hline \multicolumn{1}{c}{ Indicators } & \multicolumn{1}{c}{ Countries with the worst conditions } \\
\hline Social Inequality & Brazil, South Africa and Rwanda \\
ICT infrastructure & Rwanda, São Tomé and Príncipe and South Africa \\
Education & São Tomé and Príncipe and Rwanda (no data for Brazil) \\
Innovation & Rwanda, South Africa, Brazil (no data for São Tomé) \\
\hline
\end{tabular}

Source: Own elaboration based on Notre Dame global adaptation initiative: download data (2020).

After reviewing the data on the countries' climate vulnerability, some conclusions will be presented that might guide the analysis on the tendency of securitization. Rwanda was the most vulnerable country in 1995 , but it reduced its level of vulnerability through time more noticeably than all others. Brazil also reduced its vulnerability, going from a highly vulnerable to a medium position. The same happened to Mauritius. The least vulnerable countries also improved, though to a lesser extent. 
The most vulnerable countries face challenges in practically all dimensions, variables and indicators, which is obvious. However, this indicates difficulty overcoming this condition, i.e., these countries will have to expend a lot of effort in mitigation and adaptation policies. These challenges can lead to the use of securitization as a strategy to attract attention and gain international support.

Some aspects of the index's components are worthy of attention: the relative proximity between Brazil and South Africa in some important indicators, though for different reasons, especially when it comes to sensitivity and exposure to transformation due to climate change, to the capacity indicators and to readiness. These elements bring countries with high and medium vulnerability together due to the challenges involved in overcoming the conditions that cause and maintain their vulnerability to GCC. Therefore, it is possible that countries with medium vulnerability will also securitize certain issues, in a strategy similar to those of high vulnerability.

\section{Debating the securitization hypothesis}

As mentioned before, all attempts of securitization involve three elements: existential threat, emergency and possibility of rule-breaking ${ }^{5}$ (Buzan et al. 1998). This process takes place at the level of speech, since every securitization process relates to the perception of a supposed threat, and not necessarily the existence of danger in objective terms.

This section will analyze the documentation presented, ${ }^{6}$ as well as check the securitization tendencies of the seven countries. Official documents from the seven chosen countries will be analyzed, in search of elements that point to mentions of existential threat and emergency situation. The analyzed documents were selected from governmental agencies. The documents have been chosen among reports, plans and forums which clearly had the GCC as their main topic.

The search for the third element, possibility of rule-breaking, was not carried out, since the source of this research is official documents. We are supposing that no government institution or authority will announce their own misdemeanors, although it is common that rule-breaking occurs in the name of a country's security and its government, and speeches are only used to justify it. The chosen documents are listed at the end of this paper under "Analyzed Documents," after the references.

This analysis will be based on the frequency of the terms 'security,' 'risk,' 'danger,' 'hazard,' 'menace' and 'peril' in the analyzed documents. All these terms can be related to a supposed existential threat. We suppose that the more these terms come up in official documents, the better

\footnotetext{
5 Several authors, when analyzing the GCC securitization processes, prefer to create their own criteria for verifying these movements. Diez et al. (2016), for example, create a model in which there is no opposition between the scope of politics and that of security. In this way, the field of politics would share a place with narratives about danger and risk, forming a unique space within which the speeches on security would articulate in perpendicular movements, sometimes demanding urgent and contingent policies, sometimes just alerting to the need for actions within bureaucratic instruments of states. In the present work, we chose to keep the original model of Buzan et al. (1998), in which securitization would be the extreme politicization of a theme in a linear continuum.

${ }^{6}$ MAXQDA software was used for this analysis.
} 
the chance of an attempt to securitize GCC. In regard to emergency situations, the selected terms are 'emergency,' 'pressing,' 'urgency,' 'immediate,' 'urgent,' 'critical,' 'imminent' and 'immediate.'

After identifying the terms related to existential threats and emergency situations, both variables were added to each of the chosen countries. As the extent of the documents differed from country to country, we calculated the relative frequency of the terms in comparison to the size of the analyzed document. The results are shown in the Chart 9.

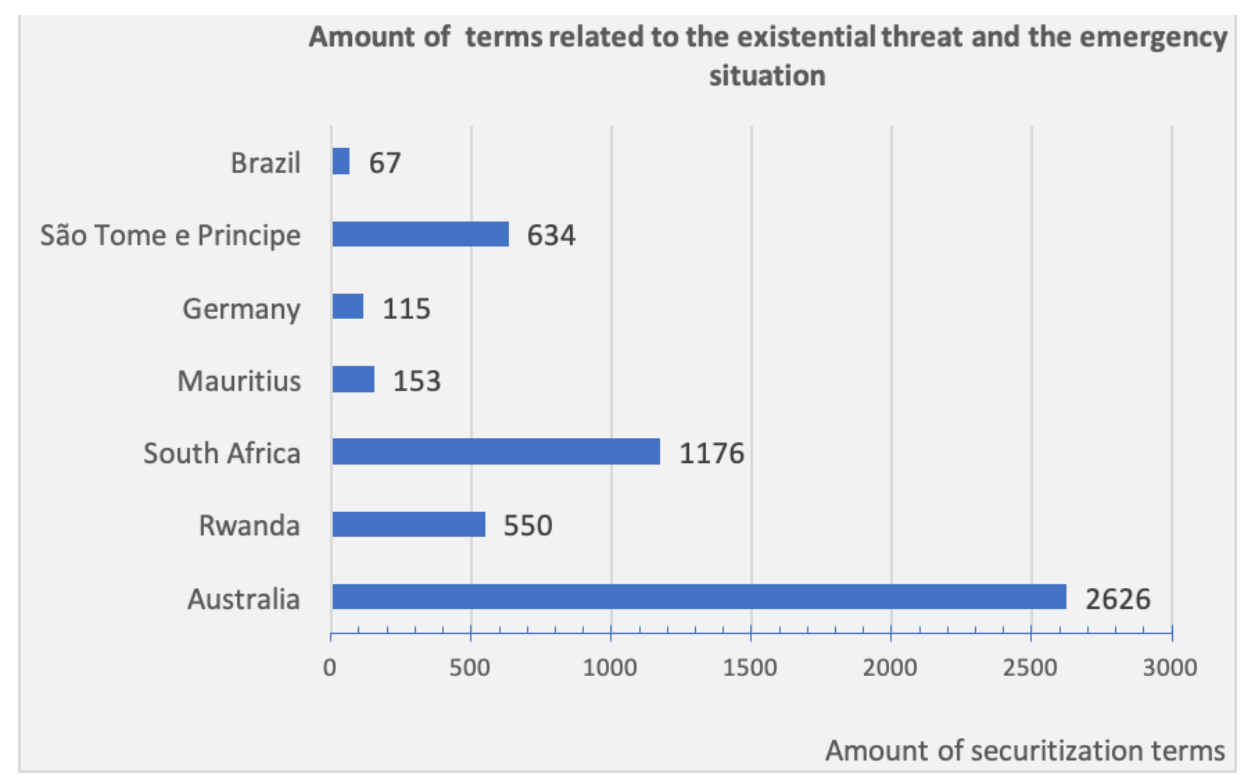

Source: Own elaboration based on documents listed in "Analyzed Documents"

\section{Chart 9. Frequency of terms related to securitization}

In regard to attempts of securitization, it can be observed that only Australia and South Africa present meaningful attempts to deal with GCC-related issues as a matter of security, as it is undeniable that they appear in the analyzed documents. In Rwanda and São Tomé and Príncipe, the terms come up less frequently in comparison to the two previous countries. Documents from Mauritius, Germany ${ }^{7}$ and Brazil present low occurrence of the terms, which indicates no securitization of the issue in official documents.

However, in order to ensure methodological rigor, one must analyze the terms in their relative occurrence, as the extent of the documents differs considerably from one another. The comparative percentage ${ }^{8}$ of terms related to securitization based on the total of pages of the documents is showed in Chart 10.

\footnotetext{
7 Other studies also analyze the GCC securitization in a slightly different way from those presented here. Diez et al. (2016), for example, conclude that the GCC securitization process in Germany is ambivalent. While this country was one of the first to draw attention to the aforementioned theme (systematic attempts to securitize the GCC in Germany have existed since the 1980s), the country has always oscillated between guaranteeing policies to reduce damage caused by the GCC and episodes of disrespect to the goals established to mitigate the effects of these changes. These conclusions, however, cannot be considered opposites in absolute terms, since this study proposed to analyze the effectiveness of securitization movements (through semi-structured interviews with diverse audiences) and not only attempts of securitization by governments, as is the case of our research.

${ }^{8}$ Percentage of securitization terms identified considering all words of analyzed documents for each country. Higher numbers indicate more words.
} 


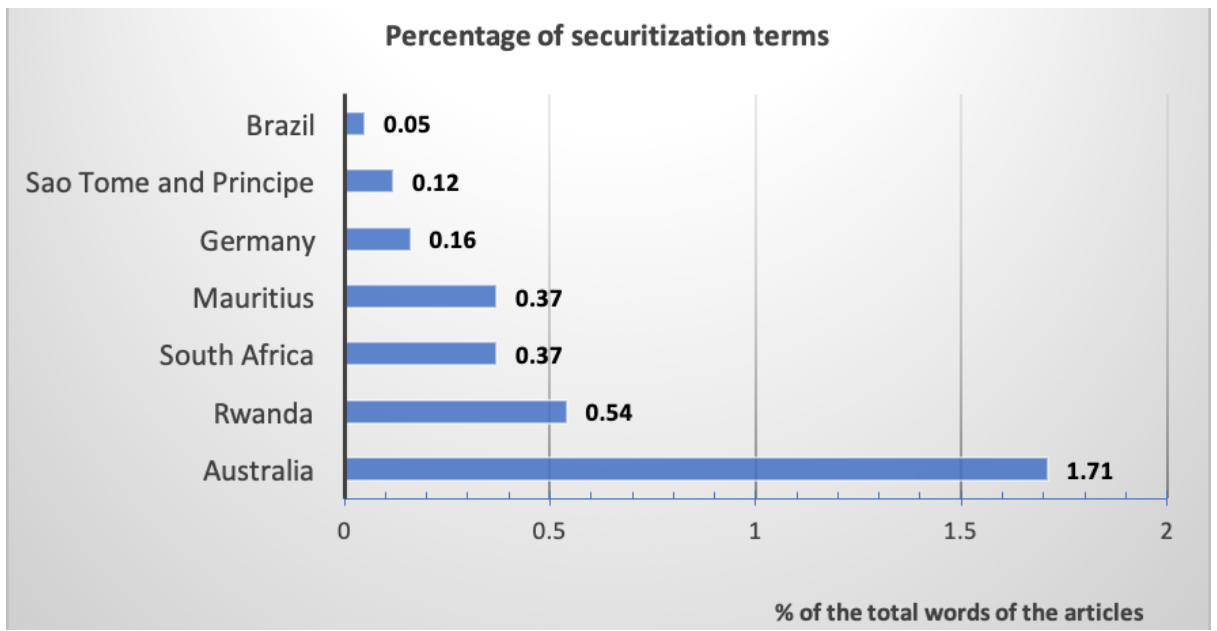

Source: Own elaboration based on documents listed in "Analyzed Documents".

\section{Chart 10. Percentage9 of terms related to securitization}

As a result, chart 10 allows for a more accurate view of what the frequency of the selected terms represents in percentage. The chart indicated that, in relative terms, only Australia presents strong evidence of securitization attempts, followed by Rwanda, South Africa, Mauritius, Germany, Brazil and São Tomé and Príncipe in that order. The two latter countries present an insignificant tendency to securitize the issue, considering the extent of the documents analyzed and the presence of securitizing elements.

In order to check if the presented hypothesis is valid, one must also compare this percentage to each country's position ${ }^{10}$ on the ND-GAIN Index Country Ranking, to verify if there is a link of proportionality between the variables. The results are shown in charts 11 and 12 .

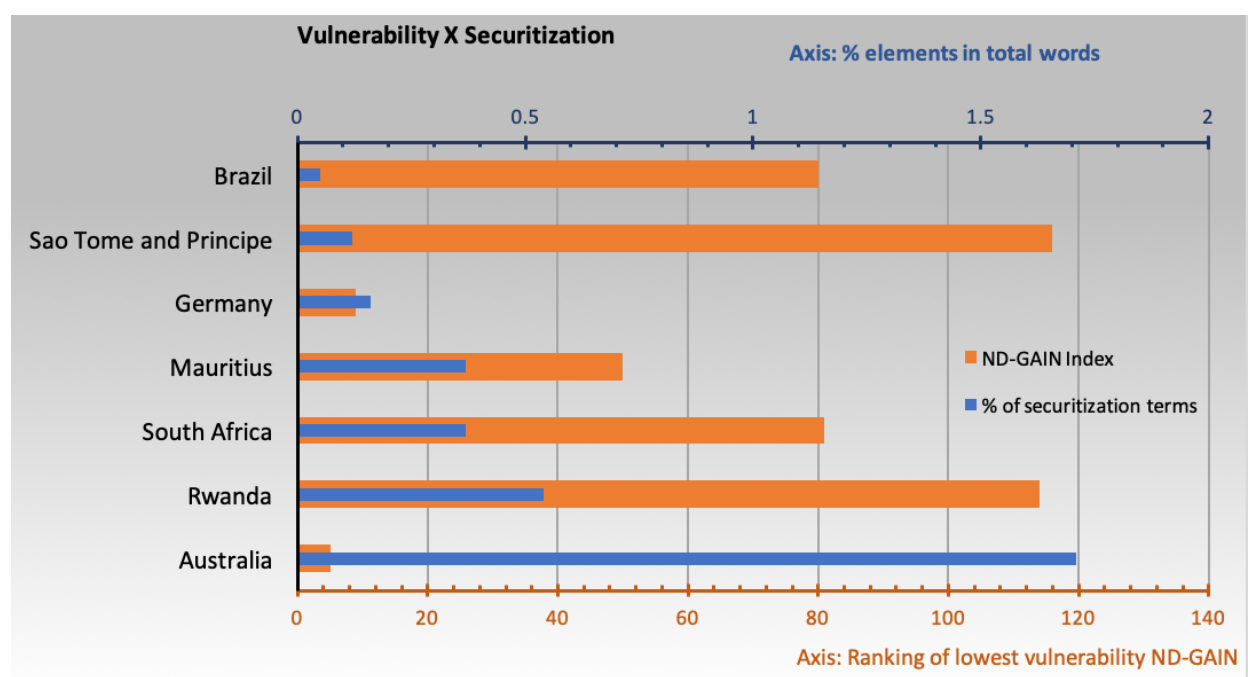

Source: Own elaboration based on Notre Dame global adaptation initiative: download data (2020).

\section{Chart 11. Position ${ }^{11}$ on ND-GAIN}

\footnotetext{
${ }^{9}$ Percentage of securitization terms identified considering all words of analyzed documents for each country. Higher numbers indicate more words.

${ }^{10}$ Country ranking according to the ND-GAIN index. Higher rank indicates less vulnerability and/or better readiness (low index).

${ }^{11}$ Country ranking according to the ND-GAIN index. Higher rank indicates less vulnerability and/or better readiness (low index).
} 


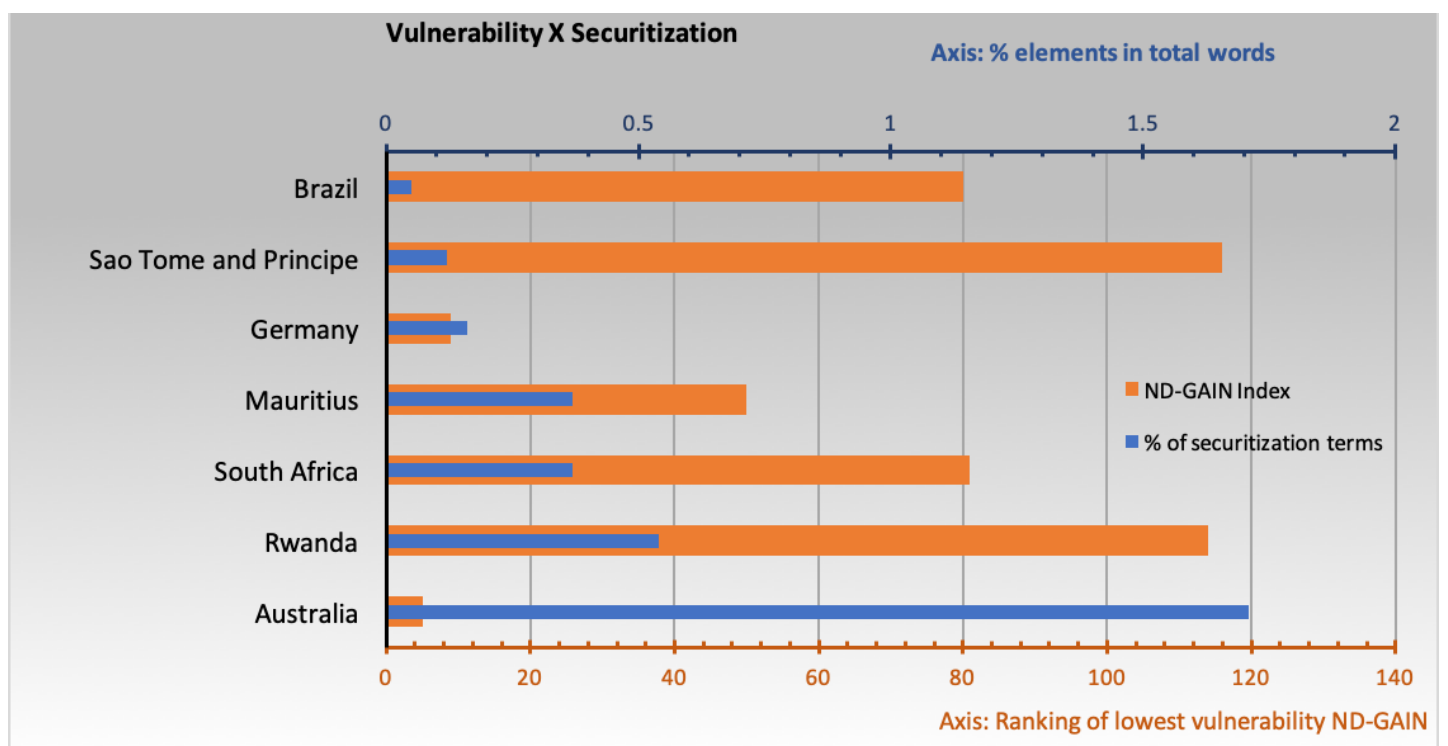

Source: Own elaboration based on Notre Dame global adaptation initiative: download data (2020) and documents listed in "Analized Documents".

\section{Chart 12. Securitization and Vulnerability}

The graphs show that high vulnerability to GCC does not necessarily mean a higher tendency to securitize the issue. This does not mean that the problem is not being dealt with, or that efforts to reduce vulnerability are not being made. Countries with high vulnerability can act within regular protocols, trying to solve the problem without treating it as an emergency or considering it an existential threat.

Likewise, countries that securitize the issue, vulnerable or not, will not necessarily succeed in attaining their goals. Identifying securitization attempts only means that the country that adopts this strategy treats the issue as a priority because it considers it a current existential threat to its reference objects.

\section{Conclusion}

The question that guided this investigation was: Does vulnerability to climate change increase or decrease a country's attempt to securitize the issue? The hypothesis tested was that the more vulnerable a country to global climate change, the larger the possibility that this agenda be securitized by the government.

To answer this question and test the hypothesis, the main theoretic categories related to vulnerability were listed, as well as securitization of international issues. Based on these definitions, we used the ND-GAIN index to measure the vulnerability of seven countries to GCC: South Africa, Germany, Australia, Brazil, Mauritius, Rwanda and São Tomé and Príncipe. Subsequently, official documents from these countries that dealt with GCC were analyzed in order to identify terms linked to existential threat and emergency situations. 
Next, the results were summed up, in order to calculate the relative presence of these terms in relation to the full extent of analyzed texts. We contrasted the results with each country's position on the ND-GAIN, in order to check whether there is a link of proportionality between the variables.

It was noted that countries with more securitizing elements, such as Australia and Rwanda, are in completely separate categories in the ND-GAIN ranking $\left(5^{\text {th }}\right.$ and $\left.114^{\text {th }}\right)$. Countries like South Africa and Mauritius, which have a medium presence of securitizing elements in the documents, rank $81^{\text {st }}$ and $50^{\text {th }}$ in the ND-GAIN respectively. Meanwhile, Germany, Brazil and São Tomé and Príncipe, countries with low levels of securitization, rank $9^{\text {th }}, 80^{\text {th }}$ and $116^{\text {th }}$, in that order.

Therefore, one can conclude that the hypothesis presented at the beginning of the study, according to which a country with a higher level of vulnerability to climate change is more likely to securitize its agenda, did not stand.

Some considerations on these results must be taken into account. First, vulnerability indicators allow countries to identify their most sensitive areas and introduce measures to face them. Second, information on these more sensitive areas, along with IPCC guidelines on adaptation policies, can be a useful tool for countries to develop policies, which decreases or maybe eliminates the need for securitization.

Furthermore, it can be said that, as emergency measures can lead to political instability, it is preferable to deal with the issue through regular institutional channels. These considerations can be the base for new research that may explain why emergency measures in environmental issues are regarded in most countries as a "non-pressing urgency," dealt with within the regular political channels.

As a result, further studies may investigate whether non-government agents have attempted to securitize the issue and, if so, check the level of efficiency, taking into account the reaction of specific audiences. Another possible study is to investigate the reason why countries so vulnerable to climate change do not feel the need to securitize the issue, while other less vulnerable ones do so.

\section{Acknowledgements}

Conselho Nacional de Desenvolvimento Científico e Tecnológico (CNPq), Coordenação de Aperfeiçoamento de Pessoal de Nível Superior (CAPES) and Fundação de Amparo à Pesquisa do Estado de Minas Gerais (FAPEMIG) APQ-O2634.

\section{Analyzed Documents}

\section{Australia:}

Australian government response to the productivity commission report: barriers to effective climate change adaptation. https://environment.gov.au/system/files/resources/af87eed2-a30b-4c49a075-5db9f307ad16/files/ag-inquiry-response.pdf 
Australia's intended nationally determined contribution to a new climate change agreement. https://www4.unfccc.int/sites/ndcstaging/PublishedDocuments/Australia\%20First/Australias\%20 Intended $\% 20$ Nationally $\% 20$ Determined $\% 20$ Contribution $\% 20$ to $\% 20 \mathrm{a} \% 20$ new $\% 20$ Climate $\% 20$ Change\%20Agreement\%20-\%20August\%202015.pdf

Climate adaptation outlook: a proposed national adaptation assessment framework.

https://www.environment.gov.au/system/files/resources/e70b19e5-e378-499b-8ae3cbb42875328c/files/climate-adaptation-outlook.pdf

Climate compass: a climate risk management framework for commonwealth agencies.

https://environment.gov.au/climate-change/adaptation/publications/climate-compass-climaterisk-management-framework

National climate resilience and adaptation strategy 2015. http:/www.environment.gov.au/ system/files/resources/3b44e21e-2a78-4809-87c7-a1386e350c29/files/national-climate-resilienceand-adaptation-strategy.pdf

\section{Brazil:}

Intended nationally determined contribution towards achieving the objective of the Unfccc. http://www.itamaraty.gov.br/images/ed_desenvsust/BRAZIL-iNDC-english.pdf

Summary report on the technical analysis of the first biennial update report of Brazil submitted on 31 December 2014. https://unfccc.int/documents/9106

National adaptation plan: 1st monitoring and evaluation report 2016-2017. https://www. mma.gov.br/images/arquivo/80182/GTTm/MonitoringReport.pdf

Documento base para subsidiar os diálogos estruturados sobre a elaboração de uma estratégia de implementação e financiamento da contribuição nacionalmente determinada do Brasil ao acordo de Paris (NDC). https://www.mma.gov.br/images/arquivos/clima/ndc/NDCDocBase.pdf

National adaptation plan: general strategy vol. I. https://www.mma.gov.br/images/ arquivo/80182/PNA_Volume\%20I_EN.pdf

National adaptation plan to climate change: sectoral and thematic strategies vol II. https://www.mma.gov.br/images/arquivo/80182/BOOK_PNA_Volume\%20II\%20v4.pdf

Technical report on the technical analysis of the technical annex to the first biennial update report of Brazil submitted in accordance with decision 14/CP.19, paragraph 7, on 31 December 2014. https://unfccc.int/resource/docs/2015/tatr/eng/bra.pdf

\section{Germany:}

Adaptation to climate change: initial progress report by the Federal Government on Germany's adaptation strategy. https://www.bmu.de/en/publication/adaptation-to-climate-change-initialprogress-report-by-the-federal-government-on-germanys-adapt/ 
The German government's climate action programme 2020. https://www.bmu.de/fileadmin/ Daten_BMU/Pools/Broschueren/aktionsprogramm_klimaschutz_2020_broschuere_en_bf.pdf

Climate action plan 2050: principles and goals of the German government's climate policy: executive summary. https://www.bmu.de/fileadmin/Daten_BMU/Download_PDF/Klimaschutz/ klimaschutzplan_2050_kurzf_en_bf.pdf

Report on the individual review of the annual submission of Germany submitted in 2014. https://unfccc.int/documents/8699

Report of the technical review of the first biennial report of Germany. https://unfccc.int/ documents/8639

Report of the technical review of the sixth national communication of Germany. https:// unfccc.int/resource/docs/2011/idr/deu05.pdf.

Summary report on the multilateral assessment of Germany at the forty-second session of the Subsidiary Body for Implementation. https:/unfccc.int/resource/docs/2015/webdocs/deu_ma.pdf

Status report of the anual inventory of Germany. https://unfccc.int/sites/default/files/resource/ docs/2015/asr/deu.pdf

\section{Mauritius:}

Intended nationally determined contribution for the Republic of Mauritius. https://www4. unfccc.int/sites/ndcstaging/PublishedDocuments/Mauritius\%20First/Final\%20INDC\%20for\%20 Mauritius\%2028\%20Sept\%202015.pdf

Final inception report: climate change adaptation report.

https://www.adaptation-undp.org/sites/default/files/downloads/final_inception_report_ august_2012.pdf

Request for project/programming funding from adaptation fund: regular project from Republic of Mauritius. https://www.adaptation-undp.org/sites/default/files/downloads/georgia_ af_2011-12-14.pdf

\section{Rwanda:}

Climate report Rwanda. https:/www.weadapt.org/sites/weadapt.org/files/legacy-new/ knowledge-base/files/505c5f348ba9crwanda-climate-final.pdf

Green growth and climate change: national strategy for climate change and low carbon development. https://cdkn.org/wp-content/uploads/2010/12/Rwanda-Green-Growth-Strategy-FINAL1.pdf

Intended nationally determined contribution (INDC) for the Republic of Rwanda. https://www4.unfccc.int/sites/ndcstaging/PublishedDocuments/Rwanda\%20First/INDC_ Rwanda_Nov.2015.pdf 
National adaptation programmes of action to climate change: NAPA-Rwanda. http://www. fonerwa.org/sites/default/files/National\%20Adaptation\%20Programmes\%20of\%20Action\%20 to\%20Climate\%20Change\%20\%28NAPA\%29\%20-\%202009.pdf

Technology needs assessment and technology action plans for climate change mitigation and adaptation. http://www.fonerwa.org/sites/default/files/Technology\%20Needs\%20Assessment $\% 20$ $\% 26 \% 20$ Technology\%20Action \%20Plans\%20For\%20Climate $\% 20$ Change $\% 20$ Mitigation $\% 20$ \%26\%20Adaptation\%20in\%20Rwanda.pdf

Annual report 2017/2018. https:/www.environment.gov.za/sites/default/files/reports/ environmental_affairs_annualreport2017_18.pdf

\section{São Tomé and Príncipe:}

Democratic Republic of Sáo Tomé and Príncipe: poverty reduction strategy paper. http://citeseerx.ist.psu.edu/viewdoc/download;jsessionid=169ACBE96BE8D1012356EAE38F 7B91E3?doi=10.1.1.589.385\&rep=rep 1 \&type=pdf

Intended nationally determined contribution. https:/www4.unfccc.int/sites/ndcstaging/ PublishedDocuments/Sao\%20Tome\%20and\%20Principe\%20First/STP_INDC\%20_Ingles_30.09.pdf

Plano de adaptação às mudanças do clima, 2006. http://dga.st/public/images/uploads/2e1 74dc023e9cf95ee3804af5530d681.pdf

Plano multisetorial de investimentos para integrar a resiliência às alteraçóes climáticas e riscos de desastres na gestão da zona costeira de São Tomé and Príncipe. http://documents.worldbank.org/ curated/en/465151520904870329/pdf/124204-PORTUGUESE-WP-PUBLIC-PMSI-STP-FINAL.pdf

Preparação à terceira conferência internacional sobre o desenvolvimento sustentável dos pequenos estados insulares em desenvolvimento: relatório nacional. https://sustainabledevelopment. un.org/content/documents/ 1 144238Sao\%20Tome\%20and\%20PrincipeRELATORIO \%20 SIDS\%20VERS\%C3\%83O\%20FINAL.pdf

Projeto WACA-Pamczc-STP: projeto de adaptação às mudanças do clima em zonas costeiras em São Tomé and Príncipe: fase II. http://dga.st/public/images/uploads/951c5fb30ff3cb7288ca 9147d861815c.pdf

Segunda comunicação nacional sobre mudanças climáticas. http://ambientestp.net/IMG/ pdf/SEGUNDA_COM._NACIONAL_DOC_FINAL.pdf

National adaptation programmes of action on climate change. http://www.planoc.com.pt/ media/22870/stp01.pdf

Project appraisal document on a proposed grant from the global environmental facility trust fund in the amount to the Democratic Republic of São Tomé and Príncipe for an adaptation to climate change project. http://documents.worldbank.org/curated/pt/547031468304184848/pdf /613720PAD0P111055B00public050120110.pdf 


\section{South Africa:}

National adaptation strategy: 2nd Draft for public comments. https://www.environment. gov.za/sites/default/files/reports/nationalclimate_changeadaptation_strategyforcomment_nccas.pdf

National adaptation strategy: draft for comments. https://www.environment.gov.za/sites/ default/files/docs/nas2016.pdf

National climate change adaptation strategy. https://www.environment.gov.za/sites/default/ files/reports/nationalclimate_changeadaptation_strategyforcomment_nccas.pdf

South Africa's 1st annual climate change report: theme A: a synopsis of South Africa's 2015 annual report on monitoring climate change responses: theme A. https://www.environment.gov. $\mathrm{za} /$ sites/default/files/reports/themeA_climatechangeresponse_annualreport.pdf

South Africa's 1st annual climate change report: theme B: South Africa's climate change monitoring and evaluation. https://www.environment.gov.za/sites/default/files/reports/themeB_ monitoring_evaluation.pdf

South Africa's 1st annual climate change report: theme C: Climate Change Trands, Risks, Impacts and Vulnerabilities. https://www.environment.gov.za/otherdocuments/reports/southafricas_ firstnational_climatechange

South Africa's 1st annual climate change report: theme E: monitoring the adaptation landscape in South Africa: desired adaptation outcomes, adaptation projects and the intended nationally determined contribution. https://www.environment.gov.za/otherdocuments/reports/ southafricas_firstnational_climatechange

South Africa's 2nd annual climate change report. https://www.environment.gov.za/ otherdocuments/reports/southafricas_firstnational_climatechange

Strategic plan (2019/20-2023/24) \& annual performance plan 2019/20. https://www. environment.gov.za/sites/default/files/strategic_plans/EnvironmentalAffairs_StrategicPlan20192024-AND-App2019-2020.pdf

\section{References}

Adger, W. N. "Vulnerability." Global Environmental Change 16, no. 3 (2006): 268-281. doi: https://doi.org/10.1016/j.gloenvcha.2006.02.006

Buzan, B., O. Waever, and J. Wilde. Security: a new framework for analysis. London: Lynne Rienner, 1998.

Chen, C., I Noble, J. Hellmann, J. Coffee, M. Murillo, and N. Chawla. Country index technical report. South Bend: University of Notre Dame, 2015. Accessed May 20, 2020. https://gain.nd.edu/assets/254377/nd_gain_technical_document_2015.pdf 
Diez, T., and F. von Lucke, and Z. Wellmann. The securitisation of climate change: actors, processes and consequences. New York, NY: Routledge, 2016.

Emmers, R. "Securitization." In Contemporary Security Studies, edited by A. Collins, 109125. Oxford: Oxford University, 2007.

Floyd, R., and R. Matthew. Environmental security approaches and issues. New York, NY: Routledge, 2013.

Guzzini, S. and D. Jung. Contemporary security analysis and Copenhagen peace research. New York, NY: Routledge. 2004.

Herring, E. "Military security." In Contemporary security studies, edited by A. Collins, 42-53. Oxford: Oxford University, 2007.

Keohane, R. "International institutions: two approaches." In International theory: critical investigation, edited by J. D. Derian, 279-355. New York, NY: University Press, 1995.

Keohane, R. “The demand for international regimes." International Organization 36, no. 2. (1982): 325-355. doi: https://doi.org/

Malik, S. "Challenging orthodoxies: critical security studies." In International security studies: theory and practice, edited by P. Hough, A. Moran, B. Pilbeam, and W. Stokes. New York, NY: Routledge, 2015.

McCarthy, J., O. Canziani, N. Leary, D. Dokken, and K. White. "Climate change 2001: impacts, adaptation and vulnerability." Cambridge: Cambridge University, 2001.

Notre Dame global adaptation initiative: download data. South Bend: University of Notre Dame, 2020. Accessed September 5, 2020. https://gain.nd.edu/our-work/country-index/ download-data/

Nunes, A. R. Asset for health: linking vulnerability, resilience and adaptation to climate change. Tyndall Working Paper 163. Norwich: Tyndall Centre for Climate Change Research, 2016. Accessed on October 2, 2020. https://tyndall.ac.uk/publications/tyndall-workingpaper/2016/assets-health-linking-vulnerability-resilience-and-adaptatio

Pratt, C., U. Kaly, and J. Mitchell. Manual: how to use the environmental vulnerability index (EVI). New York, NY: United Nations Environment Programme, 2014. Accessed May 25, 2020. http://islands.unep.ch/EVI Manual.pdf

Viola, E., and M. Franchini. "Brasil na governança global do clima, 2005-2012: a luta entre conservadores e reformistas." Contexto internacional 35, no. 1 (2013): 43-76. doi: https://doi.org/10.1590/S0102-85292013000100002 